\title{
Ranibizumab inhibits nuclear cataractogenesis: An optical measurement error or unexpected pharmacological effect?
}

\author{
Ranibizumab nükleer katarakt oluşumunu inhibe eder: Optik ölçüm hatası mı yoksa beklenmeyen bir \\ farmakolojik etki mi?
}

Gökhan Pekel, Semra Acer, Alper Kaşıkçı, Ramazan Yağcı, Ebru Nevin Çetin

Pamukkale Üniversitesi Tıp Fakültesi, Göz Hastalıkları AD, Denizli

\begin{abstract}
Purpose:The aim of the study is to evaluate lens nuclear optic densitometry alterations following intravitreal ranibizumab injections in patients with age related macular degeneration (AMD).

Materials and methods:Twenty-two eyes of 22 patients with wet type AMD were included in this retrospective case series. All the eyes received intravitreal ranibizumab injections as needed. The lens nucleus densitometry examinations were taken with the Scheimpflug anterior segment imaging system. The measurements were taken before the injections and at the last visit.

Results: The mean age of the patients was $68.0 \pm 8.7$ years and the mean follow up time after the first injection was $7.8 \pm 3.7$ months. An average of $2.3 \pm 1.0$ injections was performed. For all lens densitometry measurement techniques, the pre-injection values were statistically significantly higher than the postinjection values, indicating decreased nuclear opacity after the injections $(p<0.05)$.

Conclusion: Our results show that intravitreal ranibizumab injection may have an inhibitory effect on nuclear cataract formation.
\end{abstract}

Pam Med J 2015;8(1):35-38

Key words: Intravitreal injection, ranibizumab, cataractogenesis, lens optic densitometry.

\section{Özet}

Amaç:Yaşa bağlı maküla dejenerasyonu (YBMD) hastalarında intravitreal ranibizumab enjeksiyonu sonrası lens nükleus optik dansitometre değişikliklerini değerlendirmek.

Gereç ve yöntem: Bu geriye dönük vaka serisine 22 yaş tip AMD hastasının 22 gözü dahil edildi. Her göze intravitreal ranibizumab enjeksiyonu, ihtiyaca göre protokolünde uygulandı. Lens nükleus optik dansitometre ölçümleri ön segment Scheimpflug görüntüleme cihazıyla gerçekleştirildi. Ölçümler enjeksiyonlar öncesinde ve son kontrol vizitinde yapıldı.

Bulgular:Hastaların ortalama yaşı $68.0 \pm 8.7$ yıldı ve ilk enjeksiyon sonrası ortalama takip süresi $7.8 \pm 3.7$ aydı. Gözlere ortalama $2.3 \pm 1.0 \mathrm{kez}$ enjeksiyon uygulanmıştı. Her lens densitometre ölçüm tekniğinde, ilk ölçüm değerleri son ölçüm değerlerinden istatistiksel olarak daha büyüktü $(p<0.05)$. Bu durum, enjeksiyonlar sonrası azalmış lens nükleus opasitesine işaret etmekteydi.

Sonuç: Bulgularımız göstermektedir ki, intravitreal ranibizumab enjeksiyonu, nükleer katarakt oluşumunda inhibe edici bir etkiye sahip olabilir.

Pam Tıp Derg 2015;8(1):35-38

Anahtar sözcükler: İntravitreal enjeksiyon, ranibizumab, katarakt oluşumu, lens optik dansitometre.

\section{Introduction}

Age related macular degeneration (AMD) is one of the leading causes of blindness worldwide $[1,2]$. AMD has two types such as wet and dry. The wet type AMD is characterized with choroidal neovascularization and treated with intravitreal anti vascular endothelial growth factor (anti-VEGF) agents such as ranibizumab $[3,4]$. Ranibizumab is a monoclonal antibody that binds to all forms of VEGF-A, thus inhibiting choroidal angiogenesis and reducing vascular permeability [3].

Intravitreal drug injections have the potential to induce cataract formation, either

Gökhan Pekel

Yazışma Adresi: Pamukkale Üniversitesi Tıp Fakültesi, Göz Hastalıkları AD, Denizli

e-mail: gkhanpekel@yahoo.com

Gönderilme tarihi: 17.08.2014

Kabul tarihi: 22.10.2014 
by pharmacological or procedure related side effects. In a recent multicenter study lasting 24 months, it was reported that cataract surgery was performed in $2.6 \%$ of patients who had undergone ranibizumab injections for wet AMD, and none were suspected to be related to the drug or injection procedure [5].

In this study, we aimed to investigate the impact of intravitreal ranibizumab on cataractogenesis. Apart from the previous reports that took only cataract surgery rates into account, we used an objective, reliable, and repeatable method for assessing cataracts: the Scheimpflug optic lens densitometry [6].

\section{Materials and Methods}

Twenty-two eyes of 22 patients with wet type AMD were included in this retrospective study. All the patients underwent intravitreal ranibizumab (Lucentis $₫$; Genentech Inc, South San Francisco, CA) injections as needed. This study was conducted in accordance with the ethical standards of the Declaration of Helsinki and was approved by the Institutional Ethical Committee. Exclusion criteria were any ocular surgery and any ocular disease other than wet type AMD. Diabetic patients were excluded. None of the eyes had a history of photodynamic therapy or intravitreal triamcinolone injection.
The eyes that had prior anti-VEGF treatments during the last 6 months were also excluded. The examinations were performed before the injections and at the last visit.

Lens nucleus densitometry measurements were taken with Pentacam HR (Oculus, Wetzlar, Germany). The Scheimflug images of 90-270 degrees were assessed. Lens densitometry (LD) measurement techniques were as follows: horizontal linear, vertical linear, areal, and three dimensional (3D). Figure 1 shows the 3D LD measurement screen of Pentacam HR. For linear LD measurements, a $2 \mathrm{~mm}$ vertical line and a 3 $\mathrm{mm}$ horizontal line at the center of the lens were drawn. For areal and 3D LD measurements, a 2 $\mathrm{mm}$ (vertical) $\times 3 \mathrm{~mm}$ (horizontal) rectangle was drawn. The Pentacam HR software calculated the linear, areal, and 3D LD values automatically.

The SPSS 17.0 software for Windows (SPSS Inc., Chicago, IL, USA) was used to analyze outcomes. 'P' values lower than 0.05 were accepted as statistically significant. The Wilcoxon signed rank test was used for comparison of LD values before and after the injections. The Pearson correlation analysis was performed in order to detect association between changes in 3D LD measurements and the number of injections.

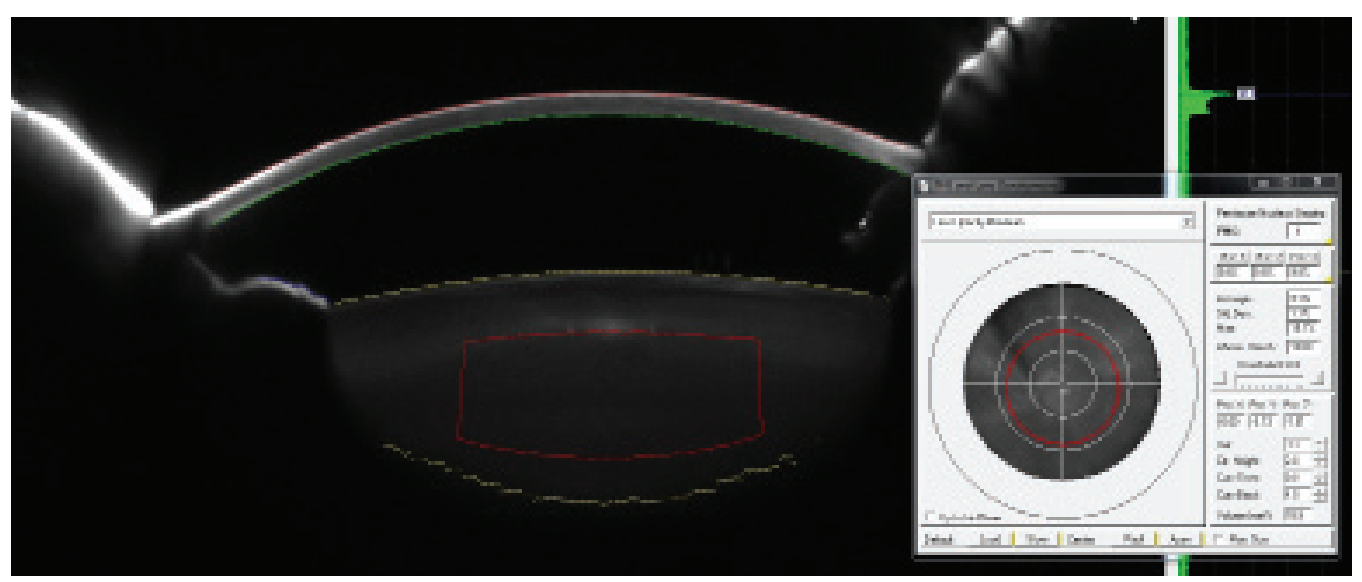

Figure 1. The 3D lens densitometry measurement screen of Pentacam HR Scheimpflug imaging system.

\section{Results}

The mean age of the patients was $68.0 \pm$ 8.7 years. The mean follow up time after the first injection was $7.8 \pm 3.7$ months (ranged from 4 to 12 months). The mean number of intravitreal injections was $2.3 \pm 1.0$ (ranged from 1 to 5 ). Table 1 shows the lens nucleus optic densitometry values of the patients. For all LD measurement techniques, the preinjection values were larger than the postinjection values, indicating decreased nuclear opacity after the injections.

According to the Pentacam Nucleus Staging (PNS) system, the cataract grades remained the same in 16 patients (\%73), decreased in 5 patients (\%23) and increased in only one patient (\%4). When follow-up time was controlled, there was no significant correlation between 3D LD changes and number of injections $(r=0.22$, $p=0.33$ ). When age was controlled, again there 
Table 1. Lens nucleus optic densitometry values of the patients are shown

\begin{tabular}{llll}
\hline & Pre-injections & Post-injections & P \\
\hline LD-horizontal & $11.65 \pm 2.45$ & $11.02 \pm 2.35$ & 0.032 \\
LD-vertical & $12.49 \pm 2.65$ & $11.72 \pm 2.44$ & 0.027 \\
LD-areal & $11.68 \pm 2.25$ & $10.81 \pm 2.18$ & 0.015 \\
LD-3D & $11.22 \pm 1.84$ & $10.59 \pm 1.89$ & 0.019 \\
\hline (LD: lens densitometry) & & & \\
\hline
\end{tabular}

was no significant correlation between 3D LD changes and number of injections $(r=0.12$, $p=0.62$ ).

\section{Discussion}

Our results show that intravitreal ranibizumab inhibits nuclear cataractogenesis to some extent in the intermediate period. At first look, the outcomes of the present study are a little bit surprising; because the main role of ranibizumab is to inhibit VEGF, and the human lens is devoid of vessels. Of course, a question arises related to this result: Is there an optical measurement error or unexpected pharmacological effect?

We think that our results should not be associated with instrument related measurement errors, since the examinations were performed by the same technique, researcher, and device. Another explanation for the outcomes of the present study may be the change of the refractive index of the vitreous (without lens nucleus changes), and thus the refractive difference at the posterior lens-vitreous border following the intravitreal injections.

The cataractogenesis inhibitory effect of ranibizumab may be related to its antiinflammatory characteristics. Although ranibizumab therapy focuses on a single pathogenic mechanism (ie. anti-VEGF), some other growth factors or cytokines may be affected by anti-VEGF treatment in the vitreous and aqueous humour [7]. This effect may take a role in inhibition of several pathways in cataract formation. Also, possible anti-oxidative effects of ranibizumab should be investigated; since oxidative processes take an important role in cataractogenesis [8].

In contrast to our results, Singer et al. reported that cataracts were more frequent in the ranibizumab treated $A M D$ patients when compared to ranibizumab untreated patients [9]. Apart from that multi-center study in which cataract diagnosis was made by subjective biomicroscopical examination, we used an objective and quantitative lens densitometry technique to evaluate the grade of the cataract. A possible reason for cataract development after intravitreal ranibizumab injection is traumatic lens damage with the tip of the needle. But in a large sample sized study that examined over seven thousand injections, it was reported that no traumatic cataracts were registered [10].

The main limitation of the present study is the lack of a control group; but the present study is a retrospective, before and after comparison study. The sample size is relatively small. Finally, follow up times should be longer in studies investigating cataract formation.

In conclusion, intravitreal ranibizumab injection decreases optic densitometry of the lens nucleus, and thus may inhibit nuclear cataract formation to some extent. Since there is no definitive medical treatment option for cataracts yet, this study should encourage researchers to conduct more comprehensive clinical and laboratory studies related to this topic.

Conflict of interest: The authors declared no conflict of interest.

\section{References}

1. Bressler NM. Age-related macular degeneration is the leading cause of blindness. JAMA 2004;291:1900-1.

2. Seddon JM, Chen CA. The epidemiology of age-related macular degeneration. Int Ophthalmol Clin 2004;44:1739.

3. Chen $Y$, Han F. Profile of ranibizumab: efficacy and safety for the treatment of wet age-related macular degeneration. Ther Clin Risk Manag 2012;8:343-51.

4. Hjelmqvist L, Lindberg $\mathrm{C}$, Kanulf $\mathrm{P}$, Dahlgren $H$, Johansson I, Siewert A. One-year outcomes using ranibizumab for neovascular age-related macular degeneration: results of a prospective and retrospective observational multicentre study. J Ophthalmol 2011;2011:405724. doi: 10.1155/2011/405724.

5. Silva R, Axer-Siegel R, Eldem B, et al. The SECURE study: long-term safety of ranibizumab $0.5 \mathrm{mg}$ in neovascular age-related macular degeneration. Ophthalmology 2013;120:130-9.

6. Kirkwood BJ, Hendicott PL, Read SA, Pesudovs K. Repeatability and validity of lens densitometry measured with Scheimpflug imaging. J Cataract Refract Surg 2009;35:1210-5.

7. Funk M, Karl D, Georgopoulos M, et al. Neovascular 
age-related macular degeneration: intraocular cytokines and growth factors and the influence of therapy with ranibizumab. Ophthalmology 2009;116:2393-9.

8. Gul A, Rahman MA, Hasnain SN, Salim A, Simjee SU. Could oxidative stress associate with age products in cataractogenesis? Curr Eye Res 2008;33:669-75.

9. Singer MA, Awh CC, Sadda S, et al. HORIZON: an open-label extension trial of ranibizumab for choroidal neovascularization secondary to age-related macular degeneration. Ophthalmology 2012;119:1175-83.

10. Rasmussen A, Bloch SB, Fuchs J, et al. A 4-year longitudinal study of 555 patients treated with ranibizumab for neovascular age-related macular degeneration. Ophthalmology 2013;120:2630-6. 